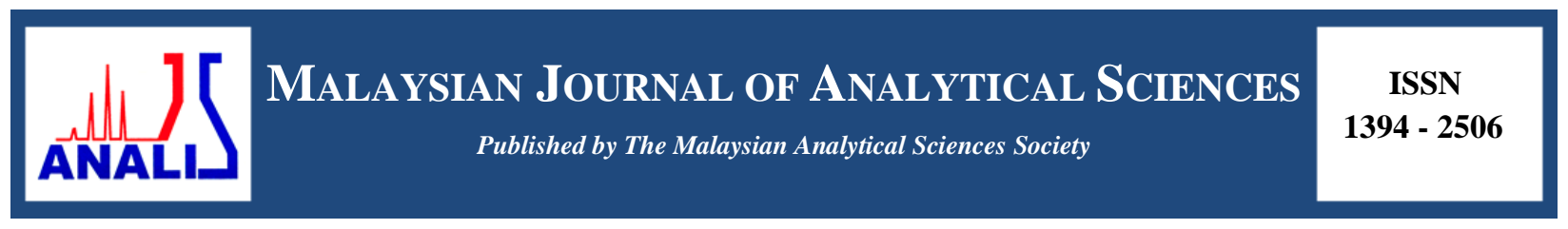

\title{
GREEN MICROWAVE-ASSISTED AQUEOUS ENZYMATIC EXTRACTION OF Elateriospermum tapos SEED OILS
}

\author{
(Pengekstrakan Hijau Minyak Bijian Elateriospermum tapos Menggunakan Kaedah Enzim \\ Berakues Berbantu Gelombang Mikro) \\ Nuraimi Azlan Hadi Tan ${ }^{1}$ and Ida Idayu Muhamad ${ }^{1,2} *$ \\ ${ }^{1}$ Department of Bioprocess and Polymer Engineering, Faculty of Chemical and Energy Engineering \\ ${ }^{2}$ IJN-UTM Cardiovascular Engineering Centre \\ Universiti Teknologi Malaysia, 81310 Johor Bahru, Johor, Malaysia \\ *Corresponding author: idaidayu@utm.my
}

Received: 25 October 2017; Accepted: 22 January 2019

\begin{abstract}
Microwave-assisted aqueous enzymatic extraction (MAAEE) is a promising green technology that is fast, efficient and energy saving. The physicochemical parameters and fatty acids composition of the MAAEE-extracted oil were reportedly quite comparable with those of solvent-extracted oil and control oil, showing no significant differences ( $p>0.05$ ) among the extraction methods. However, the oxidative stability of the MAAEE obtained oil was found to be considerably improved in the comparison as evident by the determinations of chemical profile values. Moreover, the microwave-enzymatic adjuvant improved the oil extraction yield as well as the oxidation properties of the oil produced without altering its other quality attributes. The present work compared the quality characteristics of microwave-assisted aqueous enzymatic extracted Elateriospermum tapos seed oil with those of hexane-extracted oil and control oil. Interestingly, MAAEE process has achieved 12\% and 16\% higher extraction efficiency and concentrated omega-3 fatty acid, respectively compared to non-enzymatic microwave-assisted extraction (MAE). Although resulted in lower yield than hexane-extraction (Soxhlet), MAAEE extracted $24 \%$ higher concentrated omega- 3 fatty acid with almost $99 \%$ removal of anti-nutrient amygdalin within 75 seconds. Hence the study on the interaction of extraction parameters as well as the MAAEE optimization process is sustainably feasible.
\end{abstract}

Keyword: microwave assisted aqueous enzymatic extraction, seed oils, Elateriospermum tapos, amygdalin

\begin{abstract}
Abstrak
Pengekstrakan enzim berakues yang dibantu dengan gelombang mikro (MAAEE) adalah teknologi hijau yang menjanjikan proses yang pantas, cekap dan penjimatan tenaga. Parameter fizikokimia dan komposisi asid lemak daripada minyak yang diekstrak MAAEE dilaporkan setara berbanding dengan minyak ekstrak-pelarut dan minyak kawalan serta tidak menunjukkan perbezaan ketara $(p>0.05)$ di antara kaedah pengekstrakan. Walau bagaimanapun, kestabilan oksidatif minyak MAAEE didapati lebih baik dalam perbandingan seperti yang ditunjukkan oleh penentuan nilai-nilai profil kimia. Tambahan pula, adjuvan gelombang mikro-berenzim meningkatkan hasil pengeluaran minyak serta ciri pengoksidaan minyak yang dihasilkan tanpa mengubah sifat-sifat kualiti yang lain. Kajian ini membandingkan ciri-ciri kualiti minyak biji Elateriospermum tapos secara kaedah pengekstrakan enzim berakues-berbantu gelombang mikro dengan minyak ekstrak-pelarut heksana dan minyak kawalan. Menariknya, proses MAAEE telah masing-masing mencapai kecekapan pengekstrakan 12\% dan kepekatan asid lemak omega-3 $16 \%$ lebih tinggi berbanding pengekstrakan berbantu gelombang mikro tanpa berenzim (MAE). Walaupun hasilan lebih rendah daripada pengekstrakan heksana (Soxhlet), MAAEE memperoleh asid lemak omega-3 berkepekatan 24\% lebih tinggi dengan hampir $99 \%$ penyingkiran amigdalin anti-nutrien dalam 75 saat. Oleh itu, kajian mengenai interaksi parameter pengekstrakan serta proses pengoptimuman MAAEE menunjukkan kewajaran secara lestari.
\end{abstract}

Kata kunci: pengekstrakan enzim berakues dibantu gelombang mikro, minyak bijian, Elateriospermum tapos, amigdalin 


\section{Introduction}

Microwave uses electromagnetic wave which penetrates certain materials to provide volumetric heating through ionic conduction and dipole rotation [1]. Water and aqueous based solvent system offer an increasingly crucial choice for the replacement of conventional organic solvent [2]. Therefore, the microwave assisted aqueous enzymatic extraction (MAAEE) method is a highly potential, green, fast, efficient and energy saving method which eliminates the disadvantages of conventional solvent extraction method with undesirable effect on oil quality. Moreover, the treatment of seeds with enzymes enhances the extraction of oil yield due to its hydrolyzed structural polysaccharide of the cell walls and proteins associated with the lipid bodies [3]. MAAEE had been applied for oil extraction from seed crops such as pumpkin seed [3] and Forsythia suspense seed [2]. Omega-3 fatty acid is an essential fatty acid that need to be consumed through supplements or food products due to the incapability of human body to generate the compound naturally by itself [4]. Perah or scientifically known as Elateriospermum tapos seed (ETS) is an underutilized Malaysia local plant seed that had been reported to be rich of omega-3 fatty acid (Figure 1). A research by Yong and Salimon [5] claimed that ETS contains 17.4\% of alpha linolenic acid (ALA) (PubChem CID: 5280934). The current work applies MAAEE for extraction of ETS oil, quantification of the specific amount of omega-3 fatty acid concentration and its anti-nutrient, amygdalin.

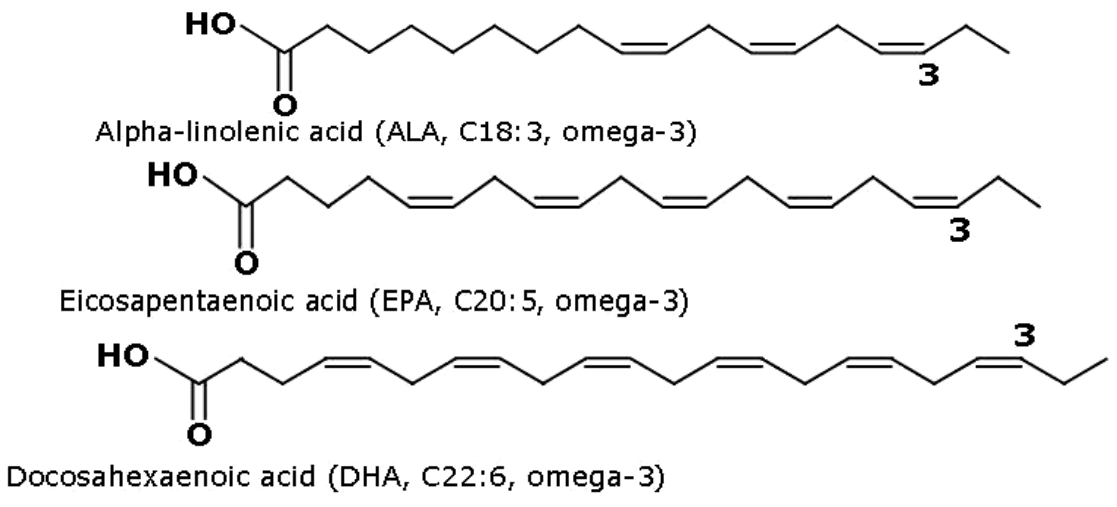

Figure 1. Properties and molecular structure of omega-3 fatty acid [6].

\section{Plant materials}

\section{Materials and Methods}

Elateriospermum tapos seed (ETS) was obtained at a local farm in Kuala Lipis, Pahang, Malaysia and was botanically identified by Biodiversity Unit, Institute of Bioscience, University Putra Malaysia (specimen voucher number SK2782/15). The seeds were manually cleaned and flooded with tap water to separate the extraneous matters (dust, vain seeds and straw from threshed seeds). The shells were removed; cleaned seeds were grinded using a laboratory grinder (MX-898M Panasonic, Malaysia) and sieved (Retsch siever, Germany) to a desired particle size and then stored at $-20{ }^{\circ} \mathrm{C}$ in airtight bags until further use. The moisture content of the seeds, which were $6-7 \%$, was determined using the infrared moisture analyser (FD-620 Kett, Japan).

\section{Reagents}

Cellulase from Aspergillus niger (Tokyo Chemical Industry), pectinase from Aspergillus niger (1.02U/mg) and proteinase from Aspergillus melleus ( $\geq 3$ units/mg solid) from Sigma Aldrich, hexane analytical and GC grade from Qrec and Merck, Malaysia.

\section{Extraction process}

For Soxhlet extraction (SE) process, $5 \mathrm{~g}$ of ETS $(0.5 \mathrm{~mm}$ particle sizes) were placed into each thimble and $150 \mathrm{~mL}$ hexane was used as a solvent. This process was carried out by refluxing each sample for 6 hours on a heating mantle. After the elapsed time, a rotary evaporator was used to evaporate the solvents. The SE extraction produced 
$48.99 \pm 0.79 \%$ of oil, which was set at $100 \%$ oil recovery in the comparison with the MAAEE in this study. Next, the samples were collected and preserved at $-20{ }^{\circ} \mathrm{C}$ in sealed bottles for further analysis.

For MAAEE method, a domestic microwave oven system was used (Sharp Model R-397J, Malaysia) equipped with digital control system for irradiation time and irradiation microwave power $(110 \mathrm{~W}, 330 \mathrm{~W}, 550 \mathrm{~W}, 770 \mathrm{~W}$ and 1100 W) and operates at $2.4 \mathrm{GHz}$. A mode stirring table was also included in microwave system to dissipate the microwave energy during microwave heating which is facilitate the extraction sample to heat up homogeneously. Subsequently, $5 \mathrm{~g}$ of grinded ETS and enzyme cocktail (cellulose: pectinase: proteinase ) ratios of 1.4:1.7:1.4 were accurately weighed and placed into a $250 \mathrm{~mL}$ flask with $1: 5$ solid to solvent ratio (based on preliminary experiment). Subsequently, the MAAEE extraction was conducted according to the design of experiment (DOE) at the following conditions; 110-1100 W irradiation power, 30-120 s extraction time, 1-5\% enzyme cocktail concentration and $0.5-1.5 \mathrm{~mm}$ particle size with a total of 30 experiment runs.

After extraction, the solution obtained from MAAEE was then centrifuged at $10000 \mathrm{rpm}$ speed for 15 minutes, and oil phase was withdrawn using a micropipette. The oil was then weighed, and the extraction yield was expressed as the mass percentage ratio (oil extracted /total oil obtained by SE method, \%) which result an optimal oil extraction yield of $46.12 \pm 1.48 \%$ at $110 \mathrm{~W}$ microwave power, $30 \mathrm{~s}$ extraction time, $1 \%$ enzyme cocktail concentration and 0.5 $\mathrm{mm}$ particle size (based on previous study). Next, the samples were collected and preserved at $-20{ }^{\circ} \mathrm{C}$ in sealed bottles for further analysis.

\section{Identification and quantification of omega-3 fatty acid concentration}

The extracted ETS oil was converted to fatty acids methyl ester (FAMEs) prior to injection. About $1 \mu \mathrm{L}$ of the sample was injected into GC (model Perkin Elmer Auto System XL) to analyze the omega-3 fatty acid. It was equipped with flame ionization detector and BPX 90 capillary column $(60 \mathrm{~m} \times 0.25 \mathrm{~mm} \times 0.55 \mu \mathrm{m})$. The detector temperature and injector temperature were programmed at $250{ }^{\circ} \mathrm{C}$. The oven temperature program was set at the initial $100{ }^{\circ} \mathrm{C}$ followed by ramp 1 at $20.0{ }^{\circ} \mathrm{C} / \mathrm{min}$ to $170{ }^{\circ} \mathrm{C}$, hold for $0.00 \mathrm{~min}$, ramp 2 at $10.0{ }^{\circ} \mathrm{C} / \mathrm{min}$ to $230{ }^{\circ} \mathrm{C}$, hold for 7 minutes and ramp 3 at $30^{\circ} \mathrm{C} / \mathrm{min}$ to $250{ }^{\circ} \mathrm{C}$, hold for 2 minutes. Nitrogen was used as the carrier gas. Subsequently, the peaks detected by the retention time were identified by comparing the result produced with standards under the same condition. Different concentrations (100, 200, 300, 400, 500, 600, 700, 800, 900 and 1000 ppm) had been prepared from omega-3 fatty acid (alpha linolenic acid) standard (Sigma Aldrich, Germany). The standards were injected in GC using the same condition of fatty acids analysis. The calibration curve of absorbance versus concentration graph was plotted. The concentration of extracted omega- 3 was determined in $\mathrm{mg}$ of $\omega-3 / \mathrm{g}$ of oil using equation 1.

$$
C_{\omega-3}=\frac{[C \times V]}{W_{o i l}}
$$

$\mathrm{C}_{\omega-3}$ indicates the concentration of the extracted omega-3, mg of $\omega-3 / \mathrm{g}$ of oil; $\mathrm{C}$ indicates the concentration of omega-3 obtained from calibration curve, $\mathrm{mg} / \mathrm{mL}$; V indicates the volume of omega-3 fatty acid solution, $\mathrm{mL}$ and $\mathrm{W}_{\text {oil }}$ is the weight of the extracted oil, g.

\section{FTIR analysis}

The chemical structure of ETS oil extracted by MAAEE, MAE and SE were determined by FTIR spectrometer (Perkin-Elmer Spectrum One) equipped with a deuterated triglycine sulphate (DTGS) as a detector and a $\mathrm{KBr} /$ Germanium as a beam splitter. A few drops of ETS oil were put onto the ATR multibounce plate of crystal at controlled ambient temperature $\left(25^{\circ} \mathrm{C}\right)$. For each analysis of sample, the ATR plate was carefully cleaned with methanol and dried with spot light to efficiently remove the traces of oil as well as to avoid any interference of the results. All spectra were scanned over the wave number interval of 4000 to $400 \mathrm{~cm}^{-1}$ with an average of 16 scans at resolution of $4 \mathrm{~cm}^{-1}$.

\section{Results and Discussion}

In Table 1, MAAEE method extracted omega-3 fatty acid at 3.3 fold greater which is about $24.2 \%(\mathrm{w} / \mathrm{w})$ higher compared to SE, and almost 2 fold greater when compared to MAE. The result shows highly significant differences 


\section{Azlan \& Ida Idayu: GREEN MICROWAVE-ASSISTED AQUEOUS ENZYMATIC EXTRACTION OF}

Elateriospermum tapos SEED OILS

by all method at $\mathrm{p}<0.05$. This shows the ability of MAAEE method to extract large concentration of omega-3 fatty acid.

Table 1. Omega-3 concentration obtained by SE, MAE and MAAEE

\begin{tabular}{lcc}
\hline $\begin{array}{l}\text { Extraction } \\
\text { Method }\end{array}$ & $\begin{array}{c}\text { Retention Time } \\
\text { (minutes) }\end{array}$ & $\begin{array}{c}\text { Concentration } \\
\text { mg } \boldsymbol{\omega}-\mathbf{3} / \mathbf{g} \text { oil }\end{array}$ \\
\hline $\mathrm{SE}$ & 12.674 & $106.57 \pm 4.32^{\mathrm{a}}$ \\
$\mathrm{MAE}$ & 12.687 & $184.92 \pm 10.60^{\mathrm{b}}$ \\
MAAEE & 12.696 & $348.96 \pm 24.88^{\mathrm{c}}$ \\
\hline $\mathrm{a}, \mathrm{b}, \mathrm{c}$ different letters show significantly different $(\mathrm{p}<0.05)$
\end{tabular}

The improved extractability of omega-3 fatty acid concentration might be due to the polar properties of the solvent used in the extraction method. Soxhlet extraction used hexane (non-polar solvent) as solvent whereas MAAEE and MAE methods used aqueous based solvent. The presence of polar compound such as water, ethanol, and methanol tend to increase the yield of omega-3 fatty acid during the extraction. According to the report by Sánchez-Camargo [7], who extracted omega-3 using supercritical fluid extraction which involved co-solvent of ethanol, the yield of omega-3 compositions was increased with increase of ethanol composition. This could be due to the omega-3 fatty acid is bonded better to more polar molecules [7]. In addition, assistance by microwave heating shows a good increment of omega-3 fatty acid concentrations as can be observed in Table 1.

Microwave energy rapidly heats up the sample directly which encourage the dipole rotation of the molecules and the migration of the ion that enhances the penetration of the solvent in matrix, disrupt the cell wall and released the intracellular product into the surrounding solvent [8]. Nevertheless, MAAEE method produced omega-3 fatty acid concentrations that is $16.4 \%$ higher compared to the MAE method. Enzyme cocktail together with the aqueous based solution in MAAEE lead to more effective solubilization and hydrolysis of the proteins through protein network breakdown of the cotyledon cells, and in the protein (olesin) based membranes surrounding lipid bodies indicating more oil being released into the solvent [9]. Therefore, it is verified that the addition of enzyme cocktail in microwave assisted extraction improve the extraction of omega-3 fatty acid compound. Fatty acids profiles of ETS oil extracted by difference techniques extraction were also compared to evaluate the performance of MAAEE technique (Table 2).

From the result exhibited in Table 2, nine main components comprised of four saturated fatty acids (SAFA), three monounsaturated fatty acids (MUFA) and two polyunsaturated fatty acids (PUFA) were identified. Palmitic acid C16.0 (13.10-13.51\%) and stearic 18:0 (3.8-5.45\%) were the most predominant SAFA; oleic acid C18:1 (34.00$34.64 \%)$ was the principle MUFA; linoleic acid C18:2 (32.61-34.65\%) and linolenic acid C18:3 (11.23-14.99\%) were two main compounds of PUFA. These values are like those reported by Yong and Salimon [5], with difference about 0 to $4 \%$. The comparison of SE, MAAEE and MAE techniques for ETS oil shows that the values of fatty acids had no significant difference $\mathrm{p}>0.05$ except palmitic acid, linoleic acid (omega 6 fatty acid) and linolenic acid (omega-3 fatty acid) $\mathrm{p}<0.05$. Microwave irradiation could break cell walls through the internal heating and enhance the volume swelling of the cells in the seed kernels. Combination with enzyme cocktail would adequately destruct the oil bodies and cell walls to expedite oil release though the breakdown of the protein network of cotyledon cells and olesin based membranes surrounding the lipid bodies [2, 9]. 
Table 2. Fatty acid profile of ETS oil

\begin{tabular}{lcccc}
\hline Fatty Acid & \multicolumn{4}{c}{ Composition (\%) } \\
& SE & MAE & MAAEE & Lipid extraction [5] \\
\hline Myristic acid (14:0) & $0.06 \pm 0.04^{\mathrm{a}}$ & $0.11 \pm 0.04^{\mathrm{a}}$ & $0.04 \pm 0.05^{\mathrm{a}}$ & $0.06 \pm 0.01$ \\
Palmitic acid (16:0) & $13.44 \pm 0.11^{\mathrm{b}}$ & $13.51 \pm 0.15^{\mathrm{b}}$ & $13.10 \pm 0.05^{\mathrm{a}}$ & $13.40 \pm 0.07$ \\
Palmitoleic acid (16:1) & $0.37 \pm 0.17^{\mathrm{a}}$ & $0.16 \pm 0.01^{\mathrm{a}}$ & $0.11 \pm 0.01^{\mathrm{a}}$ & $0.11 \pm 0.01$ \\
Stearic acid (18:0) & $3.68 \pm 1.09^{\mathrm{a}}$ & $5.44 \pm 0.04^{\mathrm{a}}$ & $5.45 \pm 0.15^{\mathrm{a}}$ & $3.59 \pm 0.02$ \\
Oleic acid (18:1) & $34.59 \pm 0.70^{\mathrm{a}}$ & $34.68 \pm 0.06^{\mathrm{a}}$ & $34.00 \pm 0.37^{\mathrm{a}}$ & $32.53 \pm 0.17$ \\
Linoleic acid (18:2) & $32.81 \pm 0.28^{\mathrm{a}}$ & $34.65 \pm 0.25^{\mathrm{b}}$ & $32.61 \pm 0.24^{\mathrm{a}}$ & $31.81 \pm 0.10$ \\
Linolenic (18:3) & $14.99 \pm 0.54^{\mathrm{b}}$ & $11.23 \pm 0.35^{\mathrm{a}}$ & $14.41 \pm 0.31^{\mathrm{b}}$ & $17.14 \pm 0.21$ \\
Arachidic Acid (20:0) & $0.06 \pm 0.11^{\mathrm{a}}$ & $0.18 \pm 0.00^{\mathrm{a}}$ & $0.23 \pm 0.02^{\mathrm{a}}$ & $0.22 \pm 0.01$ \\
Gadoleic Acid (20:1) & $0.03 \pm 0.02^{\mathrm{ab}}$ & $\mathrm{ND}$ & $0.03 \pm 0.01^{\mathrm{b}}$ & $\mathrm{ND}$ \\
Total saturated fatty acid & $17.24 \pm 1.34^{\mathrm{a}}$ & $19.23 \pm 0.23^{\mathrm{a}}$ & $18.83 \pm 0.27^{\mathrm{a}}$ & $17.66 \pm 0.50$ \\
Total monounsaturated fatty acid & $34.96 \pm 0.89^{\mathrm{a}}$ & $34.84 \pm 0.06^{\mathrm{a}}$ & $34.15 \pm 0.38^{\mathrm{a}}$ & $32.50 \pm 0.36$ \\
Polyunsaturated fatty acid & $47.80 \pm 0.82^{\mathrm{b}}$ & $45.88 \pm 0.61^{\mathrm{a}}$ & $47.02 \pm 0.55^{\mathrm{ab}}$ & $49.08 \pm 0.29$ \\
\hline
\end{tabular}

a, b different letters show significantly different $(\mathrm{p}<0.05)$, ND: not detected

Meanwhile, comparison of extraction techniques on the content of omega-3 fatty acid concentration shows that Soxhlet extraction obtained the lowest result $(10.66 \pm 0.43 \%)$ compared to MAAEE $(34.90 \pm 2.49 \%)$ and MAE $(18.49 \pm 1.06 \%)$. Moreover, the amount of amygdalin content could be minimized by the MAAEE technique as it gave the lowest amount as shown in Figure 2.

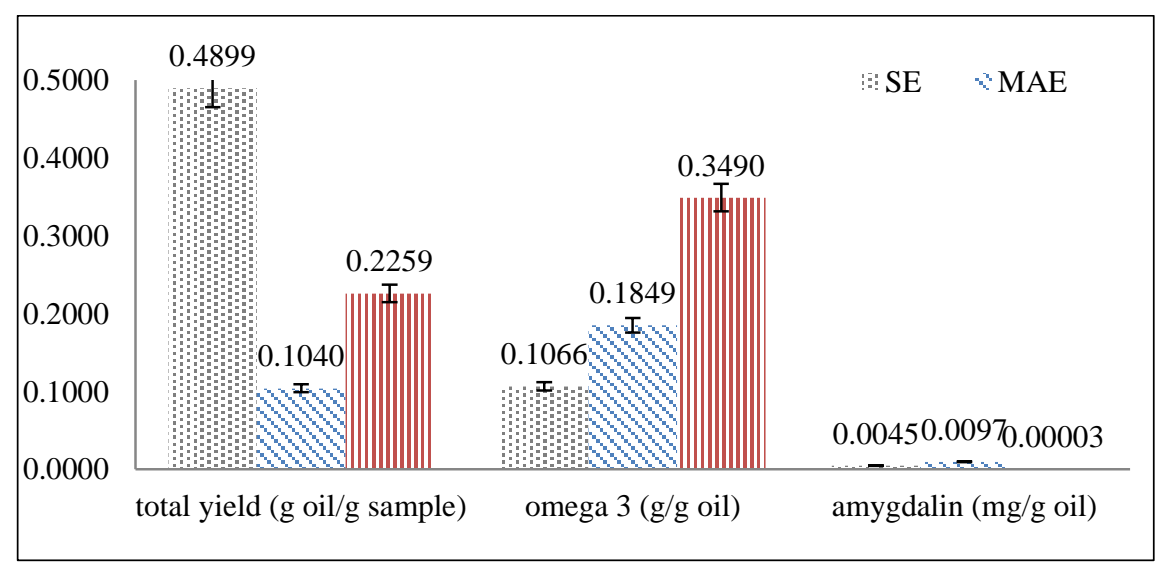

Figure 2. Comparison of the total yield, omega-3 fatty acid concentration and amygdalin concentration by SE, MAAEE, MAE techniques

The FTIR spectra of oil extracted by these techniques are very similar and the spectra feature can be related to those of triacyglycerols (90-95\%) along with the di and monoacylglycerols (5\%) and other trace levels of some components (Figure 3). 


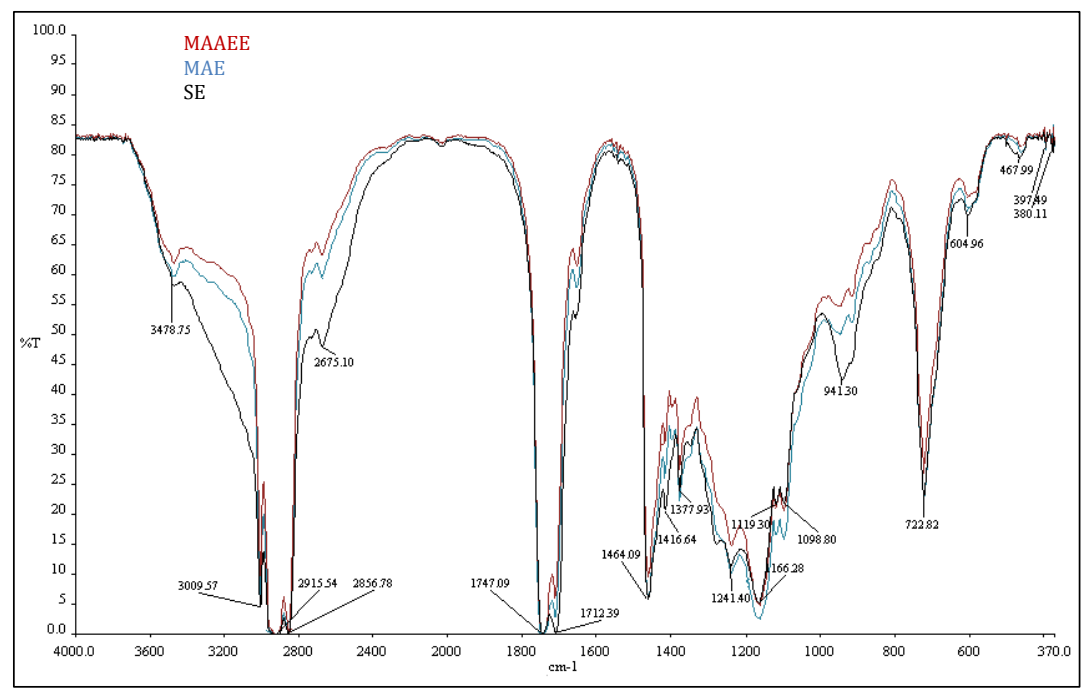

Figure 3. FTIR spectra of ETS oil by MAAEE, MAE and SE

However, minor dissimilarity on the ETS oil extracted by these techniques can be identified in terms of small band shifts and small changes in the relative peak intensity (absorbencies). The exact position of the band and peak shift is affected by the oil composition due to the changes of fatty acid proportion [10]. According to these results it can be concluded that the microwave heating and incorporation with enzyme cocktail do not change the chemical properties of the ETS oil.

\section{Conclusion}

Microwave assisted aqueous enzymatic extraction (MAAEE) technique has proven to provide the best alternative for effective and green extraction of Elateriospremum tapos seed (ETS) oil compared to microwave assisted extraction (MAE) and Soxhlet extraction (SE). MAAEE uses aqueous solution that does not involve organic solvents for extraction. MAAEE was found to improve the efficiency of extraction about $12 \%$ higher compared to MAE, but $26 \%$ lower compared to SE. The extracted ETS oil is a potential source of essential polyunsaturated fatty acids as it contains significant amount of omega-3 fatty acids (alpha linolenic acid). Using MAAEE technique, extracted omega-3 fatty acid concentration improved to $16 \%$ and $24 \%$ higher compared to using MAE (18.49 \pm $1.06 \%)$ and SE $(10.66 \pm 0.43 \%)$ techniques respectively which was identified at the retention time range of 12.67412.696 minutes. The extracted ETS oil shows good quality oil via MAAEE due to the significantly reduced amygdalin content with almost $99 \%$ was removed from $0.0097 \mathrm{mg} / \mathrm{g}$ oil (MAE), $0.0045 \mathrm{mg} / \mathrm{g}$ oil (SE) to 0.00003 $\mathrm{mg} / \mathrm{g}$ oil (MAAEE). Therefore, MAAEE is preferred as an extraction technique due to its fast extraction time $(30 \mathrm{~s})$ compared to SE which requires 6 hour extraction time resulting to MAAEE technique ability to provide high composition of linolenic acid compared to MAE.

Acknowledgement

The authors would like to thank the Ministry of Science and Innovation (MOSTI) Malaysia, the Ministry of Higher Education (MOHE) and Research Management Centre UTM for their funding support of this study.

\section{References}

1. Chan, C., Yusoff, R., and Ngoh, G. (2013). Modeling and kinetics study of conventional and assisted batch solvent extraction. Chemical Engineering Research and Design. 92(6): 1169-1186

2. Gai, Q.-Y., Jiao, J., Wei, F.-Y., Luo, M., Wang, W., Zu, Y.-G. and Fu, Y.-J. (2013). Enzyme-assisted aqueous extraction of oil from forsythia suspense seed and its physicochemical property and antioxidant activity. Industrial Crops and Products, 51: 274-278. 
3. Jiao, J., Li, Z., Gai, Q., Li, X., Wei, F., Fu, Y. and Ma, W. (2014). Microwave-assisted aqueous enzymatic extraction of oil from pumpkin seeds and evaluation of its physicochemical properties, fatty acid compositions and antioxidant activities. Food Chemistry, 147: 17-24.

4. Kapoor, R. and Patil, U. K. (2011). Importance and production of omega-3 fatty acids from natural sources. International Food Research Journal, 18: 493-499.

5. Yong, O. Y., and Salimon, J. (2006). Characteristics of Elateriospermum tapos seed oil as a new source of oilseed. Industrial Crops and Products, 24(2): 146 - 151

6. Temelli, F., Saldaña, M. D. A., Moquin, P. H. L. and Sun, M. (2008). Supercritical fluid extraction of specialty oils. Martínez, J. L. (Ed). Supercritical fluid extraction of nutraceuticals and bioactive compounds. London: CRC Press/Taylor \& Francis: pp. 52 - 99.

7. Sánchez-Camargo, A. P., Meireles, M. Â. A., Ferreira, A. L. K., Saito, E. and Cabral, F. A. (2012). Extraction of $\omega-3$ fatty acids and astaxanthin from brazilian rrdspotted shrimp waste using supercritical $\mathrm{CO}_{2}+$ ethanol mixtures. Journal of Supercritical Fluids, 61: $71-77$.

8. Li, J., Zu, Y.-G., Luo, M., Gu, C.-B., Zhao, C.-J., Efferth, T. and Fu, Y.-J. (2013). Aqueous enzymatic process assisted by microwave extraction of oil from yellow horn (Xanthoceras sorbifolia Bunge.) seed kernels and its quality evaluation. Food Chemistry, 138(4): 2152 - 2158.

9. Latif, S. and Anwar, F. (2011). Aqueous enzymatic sesame oil and protein extraction. Food Chemistry, 125(2): $679-684$.

10. Vlachos, N., Skopelitis, Y., Psaroudaki, M., Konstantinidou, V., Chatzilazarou, A, and Tegou, E. (2006). Applications of Fourier transform-infrared spectroscopy to edible oils. Analytica Chimica Acta, 573-574: 459465 . 